\title{
Sediment Sources and Dispersion on the Western Sunda Shelf, Malay Peninsula, Southern South China Sea
}

\author{
Yanguang Liu ${ }^{1,2, *}$, Chuanshun Li ${ }^{1, *}$, Ramlan Bin Omar ${ }^{3}$, Xuefa Shi ${ }^{1,2}$, Hui Zhang ${ }^{1}$ and Noraswana Nor Faiz ${ }^{3}$ \\ 1 Key Laboratory of Marine Geology and Metallogeny, First Institute of Oceanography, Ministry of Natural \\ Resources, Qingdao 266061, China; xfshi@fio.org.cn (X.S.); zhanghui@fio.org.cn (H.Z.) \\ 2 Laboratory for Marine Geology, Qingdao National Laboratory for Marine Science and Technology, \\ Qingdao 266237, China \\ 3 School of Environmental and Resources Sciences, Faculty of Science and Technology, National University of \\ Malaysia, Bangi 43600, Selangor, Malaysia; ramlan333@gmail.com (R.B.O.); iswana08@gmail.com (N.N.F.) \\ * Correspondence: yanguangliu@fio.org.cn (Y.L.); lichuanshun@fio.org.cn (C.L.)
}

Citation: Liu, Y.; Li, C.; Omar, R.B.; Shi, X.; Zhang, H.; Faiz, N.N.

Sediment Sources and Dispersion on the Western Sunda Shelf, Malay Peninsula, Southern South China Sea. Water 2021, 13, 2823. https: / / doi.org/10.3390/w13202823

Academic Editor: Alistair Borthwick

Received: 15 August 2021

Accepted: 28 September 2021

Published: 11 October 2021

Publisher's Note: MDPI stays neutral with regard to jurisdictional claims in published maps and institutional affiliations.

Copyright: (C) 2021 by the authors Licensee MDPI, Basel, Switzerland. This article is an open access article distributed under the terms and conditions of the Creative Commons Attribution (CC BY) license (https:// creativecommons.org/licenses/by/ $4.0 /)$.
Abstract: Thirty-nine surface sediment samples collected from the western Sunda Shelf off the Malay Peninsula (WSSMP) in the southern South China Sea (SCS) were analysed for grain size, major and trace elemental compositions, and light/heavy mineral contents to trace the sediment sources and their transport mechanisms in the study area. In the WSSMP, the surface sediments are relatively poorly sorted but transportable. A principal component analysis of 37 elements and grain size fractions indicates that the surface sediments can be grouped into four major assemblages in the study area. Integrating with the light/heavy minerals data in the 63-125 $\mu \mathrm{m}$ fractions of the surface sediment samples, to better trace the sediment sources of the coarse-grained components in the marine environment, the study area can be further divided into four sediment provinces. Province I is located in the northwestern part of the study area. The concentrations of $\mathrm{TiO}_{2}, \mathrm{Na}_{2} \mathrm{O}$, garnet, siderite, and glauconite in Province I were higher than in the other provinces. The main sediment source for this province originated from the Kelantan River and the Gulf of Thailand transported by the northeastern monsoon current. Province II is located offshore of the Pahang and Endau Rivers. The percentages of $\mathrm{TiO}_{2}$, rare earth elements, $\mathrm{Al}_{2} \mathrm{O}_{3}$, quartz, plagioclase, hypersthene, and magnetite in the surface sediments were typically higher in this province than in the other provinces. The Pahang and Endau rivers provide most of the sediments to this province, which are transported by southward coastal currents. Province III is located in the northeastern and eastern parts of the study area, where the coarse-grained sediment fraction had relatively high hornblende and biotite contents. Sediments in this province are mostly transported from the Mekong River during the northeastern monsoon. The other parts of the study area belong to Province IV, where the surface sediment elemental and mineral concentrations were mostly between those of the other three provinces. Therefore, we suggest that Province IV has a mixed source due to inputs from the surrounding rivers.

Keywords: Sunda Shelf; surface sediment; grain size; element; mineral; sediment provenance

\section{Introduction}

The western Sunda Shelf off the Malay Peninsula (WSSMP) is located in the southern South China Sea (SCS) and has a water depth of $<100 \mathrm{~m}$ [1]. The WSSMP connects the SCS with the Indian Ocean through the Malacca strait to the south and with the Gulf of Thailand to the northwest (Figure 1). Presently, limited work on sediment transport has been conducted in the WSSMP despite its location in the Maritime Silk Road between the SCS and Indian Ocean and its importance in studies on sediment source and sink processes in offshore environments. This is likely because the WSSMP has a smaller sediment discharge than those of the neighbouring Mekong River (110 Mt/y) to the north and Sumatra (780 Mt/year) to the south [2]. 
Previous sedimentary studies of the southern SCS have mostly focused on deep sea areas, whereas few have investigated the Sunda Shelf [3-5] or the Sunda Strait [6]. Recently, Shi et al. (2015) [7] and Liu et al. (2016) [8] discussed clay mineral and elemental distributions, respectively, in the western Gulf of Thailand, which neighbours the study area to the northwest. Until now, limited work on sediment compositions, except for trace metal and rare earth elemental compositions, has been conducted in the WSSMP [9-11]. Multi-proxy studies from the land to the ocean are required to better understand the compositions and spatial distributions of sediments on the Sunda Shelf in the southern SCS. The main objectives of this study were (1) to determine the spatial distributions of sediment compositions (including grain sizes, major and trace elemental compositions, and light and heavy mineral contents); (2) to identify the sources of surface sediments; and (3) to deduce the transport patterns of surface sediments in the marine environment and the connections of these patterns with monsoon wind-driven circulation in the WSSMP.

\section{Regional Setting}

The bedrock of the Malay Peninsula comprises Palaeozoic-Mesozoic granite, granodiorite, and Palaeozoic sedimentary rocks, which contain mudstones, sandstones, and limestones interbedded with andesitic-rhyolitic volcanic rocks [12,13]. The Malay Peninsula is part of the Sunda landmass, which has been tectonically stable since the Mesozoic period [12]. Quaternary sand-dominated sediments are distributed on the coastal plain areas of the Malay Peninsula [14].

The climate on the Malay Peninsula is affected by the East Asian monsoon without seasonal temperature variations, but with obvious differences between the dry (MarchAugust) and humid (September-February) seasons [15]. The annual average temperature is $\sim 27^{\circ} \mathrm{C}$, with a monthly difference of less than $1.1^{\circ} \mathrm{C}$. The annual rainfall of $2500-3000 \mathrm{~mm}$ is higher than that of the surrounding area and generally occurs between the relatively dry and humid seasons [16].

In the offshore region east of the Malay Peninsula, upper layer circulation is mainly controlled by monsoon winds. During the winter, surface currents flow southward along the eastern coast of the Malay Peninsula but flow northward during the summer [17]. As the largest rivers on the eastern Malay Peninsula, the Kelantan and Pahang rivers annually transport 3.0 and 2.5 million tons of sediments into the southern SCS, respectively [1]. However, the distributions of these river-transported sediments on the Sunda Shelf have not been fully determined. 


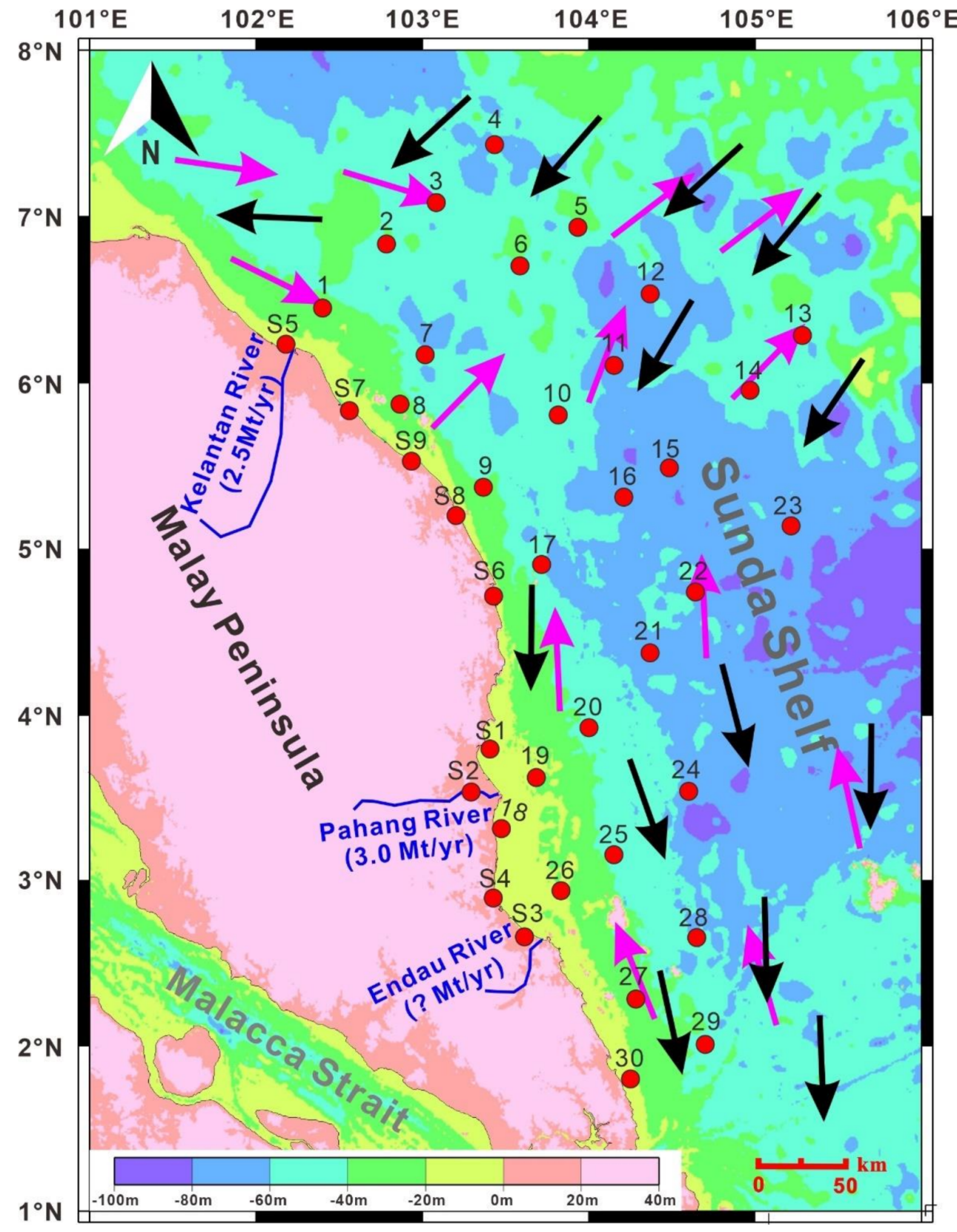

Figure 1. Distribution of surface sediment samples (red dots with numbers) collected from eastern Malaysia and the neighbouring Sunda Shelf in the southern South China Sea. The values in blue bracket refer to sediment loads of rivers, and sediment loads of the Kelantan and Pahang rivers are from [2]; sediment load of the Endau River was determined from the river drainage area and the assumption that the Endau River sediment load is similar to that of the neighbouring Pahang River. Surface circulation during the winter (black arrows) and summer (pink arrows) was modified from [17].

\section{Materials and Methods}

Surface sediment samples from the Sunda Shelf were obtained from the National University of Malaysia, and river sediment samples from the Malay Peninsula were collected between 2012 and 2013 (Table 1 and Figure 1).

Despite the proximity to land and the relatively low carbonate contents of the rivers and adjacent deltas, we removed $\mathrm{CaCO}_{3}$ and organic material from the samples using $0.1 \mathrm{~N}$ $\mathrm{HCl}$ and $10 \% \mathrm{H}_{2} \mathrm{O}_{2}$, respectively. We then measured the grain sizes of 25 surface sediment 
samples from the study area on a Malvern Mastersize laser particle sizer (Mastersizer 2000) at the First Institute of Oceanography (FIO), Ministry of Natural Resources (MNR). The grain sizes of some sediment samples were not analysed because the sediments were very coarse-grained, with almost no fine-grained particles. The grain size parameters (mean grain size, Mz; sorting coefficient, Sort; skewness, Skew; kurtosis, Kurt) were calculated using the moment method [18]. The sediment types were classified according to [19].

To determine the concentrations of major $\left(\mathrm{Al}_{2} \mathrm{O}_{3}, \mathrm{Fe}_{2} \mathrm{O}_{3}, \mathrm{Na}_{2} \mathrm{O}, \mathrm{MgO}, \mathrm{K}_{2} \mathrm{O}, \mathrm{CaO}, \mathrm{TiO}_{2}\right.$, $\mathrm{P}_{2} \mathrm{O}_{5}$, and $\mathrm{MnO}$ ) and trace elements ( $\mathrm{Li}, \mathrm{Be}, \mathrm{Sc}, \mathrm{Co}, \mathrm{Ni}, \mathrm{Cu}, \mathrm{Ga}, \mathrm{Rb}, \mathrm{Nb}, \mathrm{Mo}, \mathrm{In}, \mathrm{Cs}, \mathrm{Ta}, \mathrm{W}$, and rare earth elements (REEs): $\mathrm{La}, \mathrm{Ce}, \mathrm{Pr}, \mathrm{Nd}, \mathrm{Sm}, \mathrm{Eu}, \mathrm{Gd}, \mathrm{Tb}, \mathrm{Dy}, \mathrm{Ho}, \mathrm{Er}, \mathrm{Tm}, \mathrm{Yb}$, and $\mathrm{Lu}$ ), 39 powdered sediment samples from the study area were digested using a mixture of $\mathrm{HF}$, $\mathrm{HNO}_{3}$, and $\mathrm{HClO}_{4}$ at a ratio of 4:4:1 in low-pressure Teflon digestion vessels and heated on a ceramic hot plate at $120^{\circ} \mathrm{C}$ until the mixed solutions were completely dried. These digestion steps were repeated with additional acid until only a negligible amount of white residue remained. Then, $2 \% \mathrm{HNO}_{3}$ was added to the vessels. For reliable analytical results, Chinese national standards, i.e., certified marine (GBW07311 and GBW07313) and riverine sediments (GBW07309), were analysed with the sediment samples. The major and trace elemental compositions were analysed at FIO using inductively coupled plasma optical emission spectrometry (ICP-OES) (iCAP6300, Thermo Fisher Scientific Inc.) and inductively coupled plasma mass spectrometry (ICP-MS) (Thermo X Series 2, Thermo Fisher Scientific Inc. 168 Third Avenue Waltham, MA, USA 02451), respectively. The analytical accuracy and precision were better than $5 \%$ for the major elements and $10 \%$ for the trace elements.

Mineral data were acquired from the $63-125 \mu \mathrm{m}$ fractions and separated into light and heavy minerals using bromoform with a density of $2.80 \mathrm{~g} / \mathrm{cm}^{3}$. The separated heavy minerals were washed 2-3 times with pure ethyl alcohol, dried at a constant temperature of $60^{\circ} \mathrm{C}$, mounted on glass slides, and identified using stereomicroscopy and polarised light microscopy. At least 300 particles were identified and counted on each slide for each of the 28 surface sediment samples from the study area.

Table 1. Information of surface sediment samples taken from the eastern Malaysia and neighbouring Sunda Shelf, southern South China Sea.

\begin{tabular}{cccccc}
\hline No. & Sample & Name & Longitude $\left({ }^{\circ}\right.$ E) & Latitude $\left({ }^{\circ} \mathbf{N}\right)$ & Water Depth $(\mathbf{m})$ \\
\hline S1 & PR-10 & PRD-ST10 & 103.406 & 3.789 & 0.5 \\
S2 & PR-04 & Pahang River-ST4 & 103.293 & 3.531 & 0.5 \\
S3 & ENR & Endau River & 103.613 & 2.657 & 0.5 \\
S4 & ROR & Rompin River & 103.426 & 2.891 & 0.5 \\
S5 & KD-01 & Kelantan Delta-ST1 & 102.180 & 6.230 & 0.5 \\
S6 & KE-01 & Kemaman ST1 & 103.428 & 4.712 & 0.5 \\
S7 & KB-01 & Kuala Besut ST1 & 102.561 & 5.829 & 0.5 \\
S8 & MR-02 & Marang River-ST2- & 103.202 & 5.197 & 0.5 \\
S9 & MR-01 & Merang River-ST1 & 102.934 & 5.525 & 0.5 \\
1 & KD-34 & Delta-ST34 & 102.400 & 6.448 & 0.5 \\
2 & SF-02 & SF02 & 102.784 & 6.834 & 47 \\
3 & SF-03 & SF03 & 103.083 & 7.084 & 50 \\
4 & SF-04 & SF04 & 103.434 & 7.433 & 61 \\
5 & SF-05 & SF05 & 103.934 & 6.935 & 52 \\
6 & SF-06 & SF06 & 103.586 & 6.702 & 52 \\
7 & SF-07 & SF07 & 103.017 & 6.167 & 45 \\
8 & SF-08 & SF08 & 102.865 & 5.868 & 34 \\
9 & SF-09 & SF09 & 103.366 & 5.368 & 47 \\
10 & SF-10 & SF10 & 103.816 & 5.803 & 55 \\
11 & SF-11 & SF11 & 104.152 & 6.103 & 72 \\
12 & SF-12 & SF12 & 104.369 & 6.534 & 59 \\
\hline
\end{tabular}


Table 1. Cont.

\begin{tabular}{cccccc}
\hline No. & Sample & Name & Longitude $\left({ }^{\circ}\right.$ E) & Latitude $\left({ }^{\circ} \mathbf{N}\right)$ & Water Depth $(\mathbf{m})$ \\
\hline 13 & SF-13 & SF13 & 105.283 & 6.283 & 55 \\
14 & SF-14 & SF14 & 104.969 & 5.953 & 56 \\
15 & SF-15 & SF15 & 104.484 & 5.485 & 61 \\
16 & SF-16 & SF16 & 104.210 & 5.308 & 60 \\
17 & SF-17 & SF17 & 103.716 & 4.902 & 54 \\
18 & PR-60 & PRD-ST60 & 103.475 & 3.310 & 0.5 \\
19 & SF-19 & SF19 & 103.685 & 3.618 & 23 \\
20 & SF-20 & SF20 & 104.001 & 3.918 & 50 \\
21 & SF-21 & SF21 & 104.368 & 4.369 & 65 \\
22 & SF-22 & SF22 & 104.641 & 4.737 & 66 \\
23 & SF-23 & SF23 & 105.215 & 5.135 & 67 \\
24 & SF-24 & SF24 & 104.600 & 3.535 & 62 \\
25 & SF-25 & SF25 & 104.151 & 3.152 & 41 \\
26 & SF-26 & SF26 & 103.833 & 2.936 & 20 \\
27 & SF-27 & SF27 & 104.283 & 2.282 & 30 \\
28 & SF-28 & SF28 & 104.649 & 2.653 & 46 \\
29 & SF-29 & SF29 & 104.700 & 2.009 & 14 \\
30 & SF-30 & SF30 & 104.251 & 1.801 & \\
\hline
\end{tabular}

\section{Results}

\subsection{Sediment Types and Grain Sizes}

In the study area, the sediment samples were mainly composed of silt, while sandy silt was sporadically observed (Figure 2a). Sediment with a high percentage of sand $(>30 \%)$ was mainly observed near large river mouths (including the Kelantan, Pahang, and Endau rivers). In contrast, sediment that contained silt as the dominant component (average silt percentage of $67.2 \%$ ) generally contained low percentages of sand near the large river mouths (Figure $2 \mathrm{~b}, \mathrm{c}$ ). The sediment clay contents (average clay percentage of $10.2 \%$ ) were lower in nearshore areas than in other areas (Figure 2d).
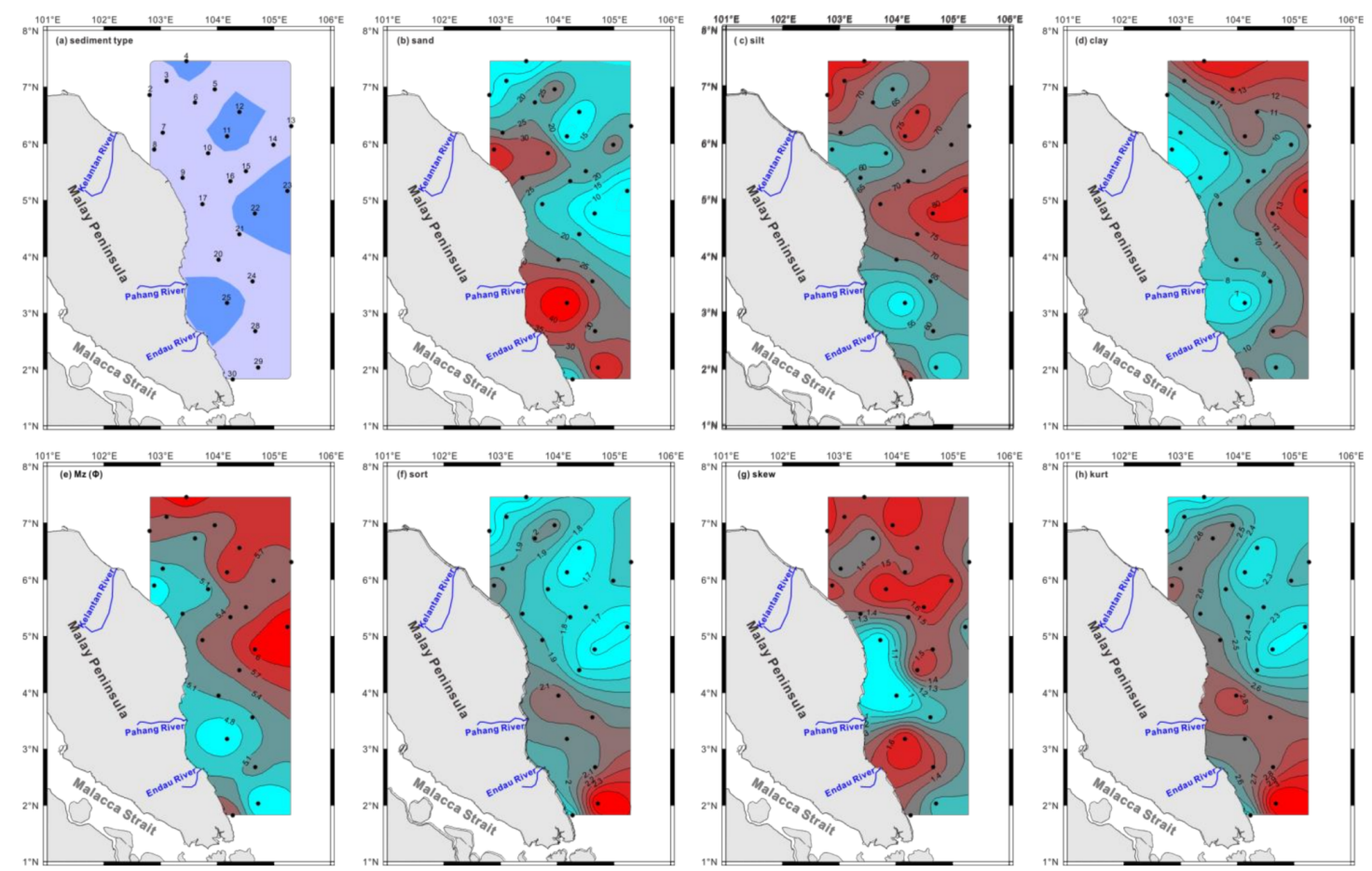

Figure 2. Locations of surface sediment samples (dark dots) used for grain size analyses on the western Sunda Shelf and the distribution of various grain size parameters in the study area. (a) Sediment type, (b) sand, (c) silt, (d) clay, (e) mean grain size (Mz, unit: $\Phi)$, (f) sort (unit: $\Phi)$, (g) skew, and (h) kurt. Dark and light blue indicate silts and sandy silts, respectively. 
According to Folk's classification [19], the sediment type classification results indicate that the sediments in the study area were silts and sandy silts (Figure 3). Previous studies have shown that sediment on the Sunda Shelf is mostly coarse-grained and deposited during glacial periods with low sea levels $[1,20,21]$. Adiana et al. (2014) suggested that re-suspension of sediment particles occurs in offshore areas near the Malay Peninsula owing to strong currents in the southern SCS $[10,22]$. Therefore, the sediment types observed in the study area were relatively coarse in offshore areas, similar to the findings of previous studies.

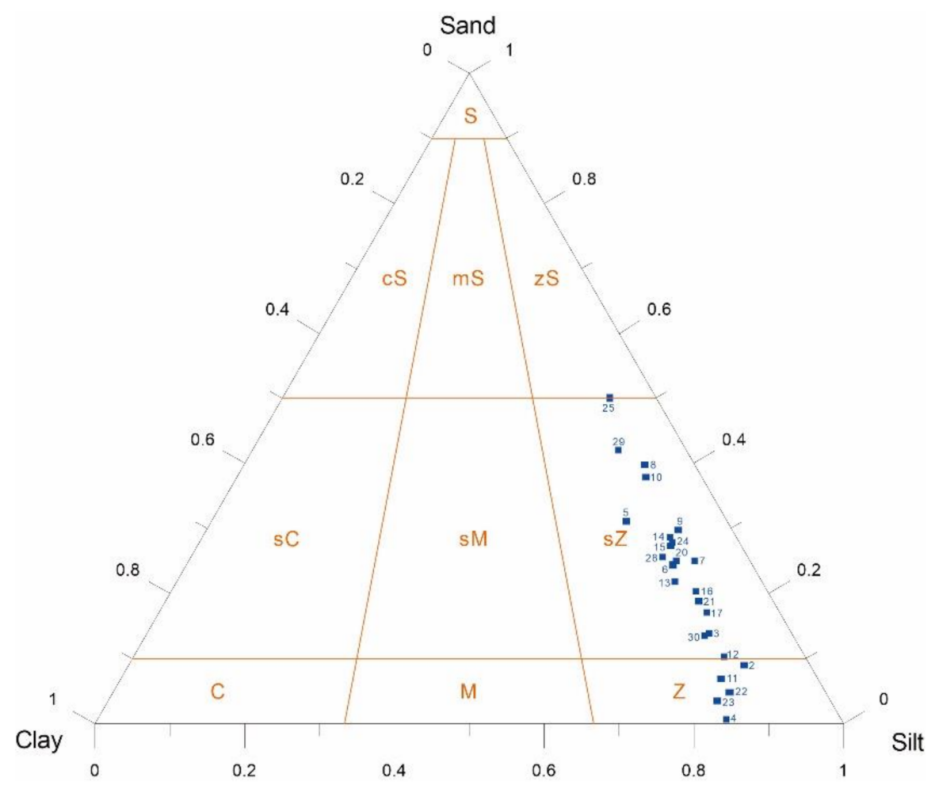

Figure 3. Classification of surface sediment types on the southwestern Sunda Shelf according to grain size composition. The abbreviations $\mathrm{S}, \mathrm{cS}, \mathrm{mS}, \mathrm{zS}, \mathrm{sC}, \mathrm{sM}, \mathrm{sZ}, \mathrm{C}, \mathrm{M}$, and $\mathrm{Z}$ represent sand, clayey sand, muddy sand, silty sand, sandy clay, sandy mud, sandy silt, clay, mud, and silt, respectively.

The average particle diameter $(\mathrm{Mz})$ ranged from $4.30 \Phi$ to $6.37 \Phi$ (average of $5.41 \Phi$ ). High Mz values $(>5.7 \Phi)$ were mainly observed on the outer Sunda Shelf to the north and east, while low Mz values $(<5.1 \Phi)$ were observed along the coast of the Malay Peninsula (Figure 2e). The sorting coefficient (sort), skewness (skew), and kurtosis values (kurt) varied from 1.52-2.69 $\Phi, 0.60-1.82$, and 2.09-3.32, respectively, with average values of $1.87,1.42$, and 2.51 , respectively. High sort values $(>2.1 \Phi)$ were mostly observed in the southeastern part of the study area, and low skew values $(<1.2)$ were observed in the northern part of the area near the mouth of the Pahang River (Figure 2f-g). Moreover, high kurt values ( $>2.6$ ) were observed along the coast of the Malay Peninsula (Figure 2h).

\subsection{Major and Trace Elemental Compositions}

The average concentrations of the major elements in descending order are as follows: $\mathrm{SiO}_{2}, \mathrm{Al}_{2} \mathrm{O}_{3}, \mathrm{CaO}, \mathrm{Fe}_{2} \mathrm{O}_{3}, \mathrm{MgO}, \mathrm{K}_{2} \mathrm{O}, \mathrm{Na}_{2} \mathrm{O}, \mathrm{TiO}_{2}, \mathrm{P}_{2} \mathrm{O}_{5}$, and $\mathrm{MnO}$. $\mathrm{SiO}_{2}$ comprised more than $59 \%$ of the elements in the sediments, ranging from 47.0 to $73.8 \%$. The $\mathrm{Al}_{2} \mathrm{O}_{3}$ content was in the range of $6.1-18.4 \%$, with an average of $10.8 \%$ (Figure 4). Trace elemental enrichments in surface sediments were in the order of $\mathrm{Sr}, \mathrm{Zr}, \mathrm{Ba}, \mathrm{Zn}, \mathrm{V}, \mathrm{Cr}, \mathrm{Ni}, \mathrm{Cu}$, and Co. The major and trace elements exhibited various distribution patterns in the study area. $\mathrm{SiO}_{2}$ contents were high in the coastal area and low in the Kelantan and Pahang estuaries. $\mathrm{Al}_{2} \mathrm{O}_{3}$ had the opposite spatial distribution from $\mathrm{SiO}_{2}$. Other major elements had similar distributions as $\mathrm{Al}_{2} \mathrm{O}_{3}$, except for $\mathrm{CaO}$, which had increasing contents with increasing distance from shore because of strong biological activity (Figure 4). Most of the trace elements had distribution characteristics opposite to those of $\mathrm{SiO}_{2}$. 

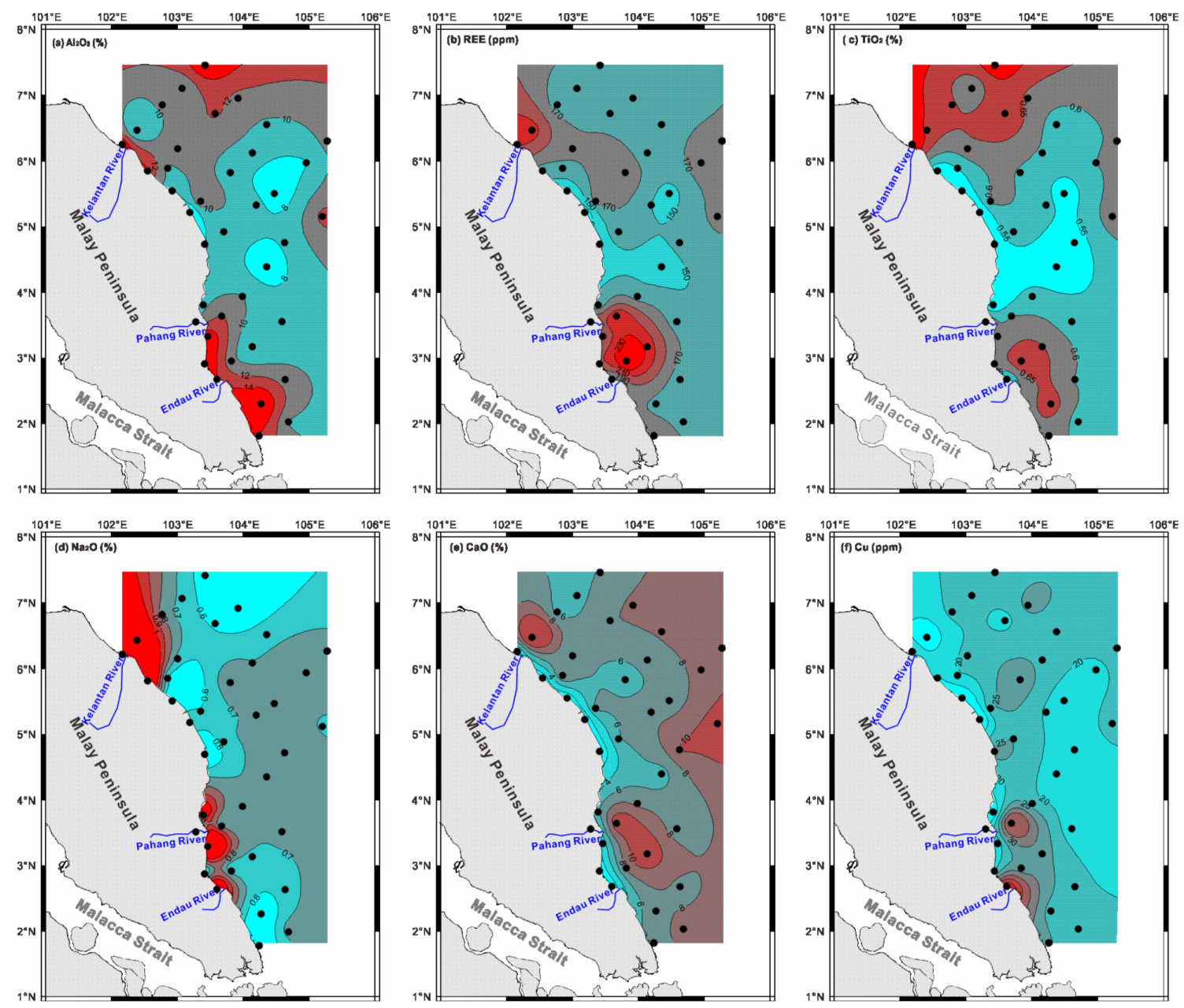

Figure 4. Locations of surface sediment types (dark dots) and the distributions of selected elements in eastern Malaysia and on the neighbouring Sunda Shelf. (a) $\mathrm{Al}_{2} \mathrm{O}_{3}$, (b) rare earth elements (REEs), (c) $\mathrm{TiO}_{2}$, (d) $\mathrm{Na}_{2} \mathrm{O},(\mathbf{e}) \mathrm{CaO}$, and (f) Cu. REEs and $\mathrm{Cu}$ in ppm, other components in \%.

\subsection{Heavy and Light Mineral Contents}

Twenty-three heavy minerals (hornblende, tremolite, epidote, biotite, muscovite(1), sericite, garnet, chlorite 1 , apatite, sphene, zircon, augite, hypersthene, siderite, ilmenite, magnetite, limonite, hematite, leucoxene, pyrite, rhodochrosite, olivine, and detrital minerals) and eight light minerals (quartz, plagioclase, K-feldspar, muscovite(2), weathered mica, glauconite, chlorite(2), and bioclasts) were identified in the surface sediment samples. Chlorite and muscovite with labels (1) and (2) denote corresponding values of the heavy and light mineral components, respectively. The detrital minerals in the surface sediments of the Sunda continental shelf were mainly light minerals, with an average weight percentage of $99.28 \%$, while the heavy minerals had an average content of less than $1 \%$. The light mineral composition mainly comprised quartz, bioclasts, glauconite, chlorite, and plagioclase. The main heavy minerals were amphibole, limonite, epidote, biotite, and siderite.

Figure 5 shows the spatial distributions of typical detrital minerals for each assemblage in the sediment samples from the study area. The Kelantan River sediments contained high percentages of glauconite $(>20 \%)$, garnet $(>0.4 \%)$, and hypersthene $(>4 \%)$. The Pahang River sediments also contained a high percentage of hypersthene $(>4 \%)$, in addition to high percentages of quartz $(>40 \%)$ and plagioclase $(>6 \%)$. The Endau River sediments contained high percentages of magnetite $(>0.9 \%)$, hypersthene $(>4 \%)$, and garnet $(>0.4 \%)$. In the marine environment, sediments from the Gulf of Thailand to the northwest contained 
high percentages of siderite $(>10 \%)$, while sediments in the northeast contained high percentages of hornblende $(>20 \%)$, quartz $(>40 \%)$, plagioclase $(>6 \%)$, and muscovite 1 $(>4 \%)$. Sediments with high percentages of sericite $(>2 \%)$ were only observed at Site SF-14, while sediments between Sites SF-15 and SF-23 contained high percentages of biotite.
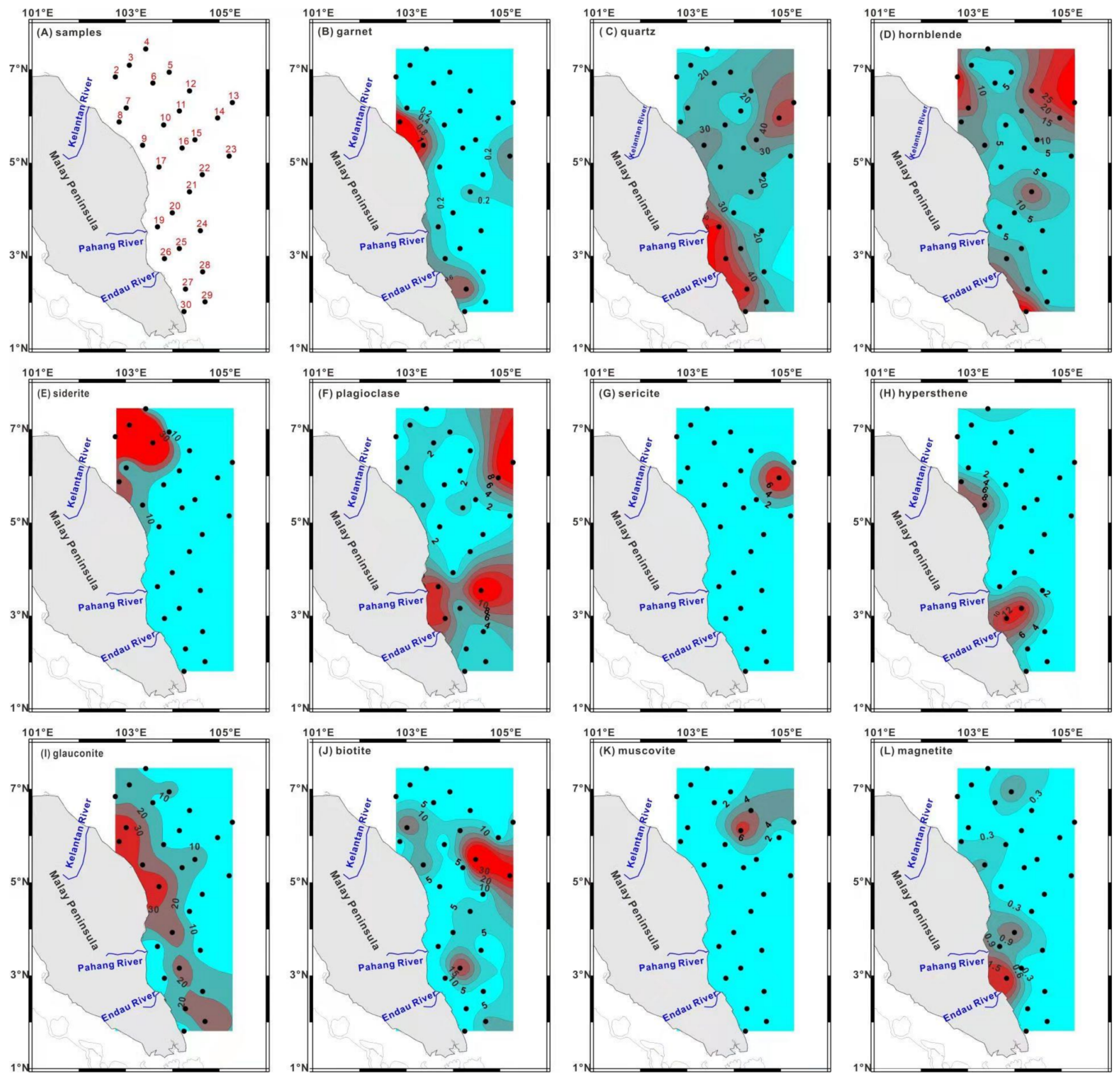

Figure 5. (A) Locations of surface sediments on the southwestern Sunda Shelf (dark dots) used for detrital mineral analyses, (B) garnet, (C) quartz, (D) hornblende, (E) siderite, (F) plagioclase, (G) sericite, (H) hypersthene, (I) glauconite, (J) biotite, (K) muscovite, and (L) magnetite.

\section{Discussion}

\subsection{Principal Component Analyses of Elements and Minerals}

To extract the common variability of the different proxies, a principal component analysis (PCA) was performed using the SPSS software package (Statistical Package for the Social Sciences, SPSS Inc. 1 New Orchard Road Armonk, New York 10504-1722 United States). Here, a PCA was conducted on the concentrations of 9 major and 28 trace elements, 
as well as the grain size compositions of the surface sediment samples. The concentrations of the 37 elements grouped the samples into six assemblages (Table 2) that explained $94.0 \%$ of the total variance.

The first principal component (PC1), which explained $36.8 \%$ of the total variance, had positive correlations with $\mathrm{Al}_{2} \mathrm{O}_{3}, \mathrm{Fe}_{2} \mathrm{O}_{3}, \mathrm{~K}_{2} \mathrm{O}, \mathrm{MgO}, \mathrm{P}_{2} \mathrm{O}_{5}, \mathrm{TiO}_{2}, \mathrm{Li}, \mathrm{Be}, \mathrm{Sc}, \mathrm{Co}, \mathrm{Ni}, \mathrm{Ga}, \mathrm{Rb}$, In, $\mathrm{Cs}$, and $\mathrm{Eu}$, as well as a relatively high $\mathrm{MnO}$ correlation. In $\mathrm{PC} 1, \mathrm{Al}_{2} \mathrm{O}_{3}$ was high $(>12 \%)$ near the Pahang, Endau, and Kelantan river mouths, with high $\mathrm{Al}_{2} \mathrm{O}_{3}$ concentrations in another area to the north (Figure 4a).

The second principal component (PC2), which explained $36.8 \%$ of the total variance, had high positive correlations with $\mathrm{Nb}, \mathrm{Ta}, \mathrm{W}$, and REEs (except $\mathrm{Eu}$ ) and relatively high correlations with $\mathrm{TiO}_{2}$ and $\mathrm{Cu}$. The REE concentrations had a spatial distribution similar to that of $\mathrm{Al}_{2} \mathrm{O}_{3}$ in the study area. Despite a similar spatial distribution to that of $\mathrm{A1}_{2} \mathrm{O}_{3}$, $\mathrm{TiO}_{2}$, which is a key proxy for tracing terrigenous inputs, had high concentrations $(>0.6 \%)$ in sediments in the northwestern area adjacent to the Gulf of Thailand (Figure $4 b-c$ ), which is likely indicative of significant terrigenous inputs from the north.

Table 2. Principal component analysis results for grain size compositions (sand, silt, and clay) and major and trace elemental compositions (including rare earth elements) of the surface sediment samples from the Malay Peninsula and the adjacent Sunda Shelf.

\begin{tabular}{|c|c|c|c|c|c|c|}
\hline Elements & PC1 & PC2 & PC3 & PC4 & PC5 & PC6 \\
\hline $\mathrm{Al}_{2} \mathrm{O}_{3}$ & 0.89 & 0.11 & 0.38 & 0.11 & -0.06 & 0.07 \\
\hline $\mathrm{CaO}$ & 0.07 & 0.42 & 0.03 & 0.00 & 0.87 & -0.14 \\
\hline $\mathrm{Fe}_{2} \mathrm{O}_{3}$ & 0.90 & 0.02 & 0.25 & -0.14 & 0.06 & 0.20 \\
\hline $\mathrm{K}_{2} \mathrm{O}$ & 0.98 & -0.01 & -0.04 & 0.09 & 0.02 & 0.01 \\
\hline $\mathrm{MgO}$ & 0.89 & 0.19 & 0.16 & -0.18 & 0.03 & 0.10 \\
\hline $\mathrm{MnO}$ & 0.54 & 0.15 & -0.19 & 0.01 & 0.56 & 0.46 \\
\hline $\mathrm{Na}_{2} \mathrm{O}$ & -0.39 & -0.05 & -0.80 & 0.04 & -0.06 & -0.24 \\
\hline $\mathrm{P}_{2} \mathrm{O}_{5}$ & 0.85 & 0.17 & -0.11 & 0.04 & 0.31 & -0.04 \\
\hline $\mathrm{TiO}_{2}$ & 0.58 & 0.52 & 0.02 & 0.06 & -0.06 & 0.48 \\
\hline $\mathrm{Li}$ & 0.96 & 0.00 & 0.21 & 0.11 & 0.03 & 0.09 \\
\hline $\mathrm{Be}$ & 0.93 & 0.19 & 0.22 & 0.01 & -0.01 & 0.02 \\
\hline Sc & 0.95 & 0.11 & 0.13 & 0.14 & -0.11 & -0.01 \\
\hline Co & 0.95 & -0.10 & -0.11 & 0.00 & 0.10 & 0.15 \\
\hline $\mathrm{Ni}$ & 0.96 & 0.04 & -0.04 & 0.02 & 0.07 & 0.19 \\
\hline $\mathrm{Cu}$ & 0.32 & 0.52 & 0.20 & -0.16 & -0.21 & 0.56 \\
\hline $\mathrm{Ga}$ & 0.93 & 0.07 & 0.17 & 0.25 & 0.02 & -0.11 \\
\hline $\mathrm{Rb}$ & 0.96 & 0.05 & 0.12 & 0.19 & 0.08 & -0.05 \\
\hline $\mathrm{Nb}$ & 0.33 & 0.81 & 0.10 & 0.23 & 0.16 & -0.09 \\
\hline Mo & 0.42 & 0.33 & 0.77 & 0.08 & -0.04 & -0.18 \\
\hline In & 0.79 & 0.18 & 0.50 & 0.15 & -0.07 & -0.17 \\
\hline Cs & 0.96 & 0.04 & 0.22 & 0.10 & -0.01 & 0.06 \\
\hline $\mathrm{Ta}$ & 0.23 & 0.88 & 0.24 & 0.06 & 0.18 & -0.04 \\
\hline W & 0.35 & 0.72 & 0.57 & 0.05 & -0.05 & -0.04 \\
\hline $\mathrm{La}$ & 0.14 & 0.95 & -0.08 & -0.18 & 0.03 & 0.03 \\
\hline $\mathrm{Ce}$ & 0.16 & 0.93 & -0.10 & -0.19 & -0.07 & 0.01 \\
\hline $\operatorname{Pr}$ & 0.22 & 0.93 & -0.11 & -0.17 & 0.07 & -0.01 \\
\hline $\mathrm{Nd}$ & 0.25 & 0.92 & -0.12 & -0.11 & 0.06 & -0.03 \\
\hline $\mathrm{Sm}$ & 0.36 & 0.90 & -0.08 & -0.12 & 0.05 & -0.06 \\
\hline $\mathrm{Eu}$ & 0.86 & 0.25 & -0.18 & 0.17 & 0.08 & -0.22 \\
\hline $\mathrm{Gd}$ & 0.23 & 0.95 & -0.02 & -0.13 & 0.10 & -0.01 \\
\hline $\mathrm{Tb}$ & 0.20 & 0.96 & 0.10 & -0.05 & 0.03 & -0.03 \\
\hline Dy & 0.05 & 0.96 & 0.13 & -0.03 & 0.03 & 0.05 \\
\hline Ho & -0.07 & 0.96 & 0.14 & -0.06 & 0.01 & 0.10 \\
\hline Er & -0.14 & 0.95 & 0.12 & -0.11 & 0.01 & 0.12 \\
\hline
\end{tabular}


Table 2. Cont.

\begin{tabular}{ccccccc}
\hline Elements & PC1 & PC2 & PC3 & PC4 & PC5 & PC6 \\
\hline Tm & -0.21 & 0.93 & 0.17 & -0.12 & 0.04 & 0.13 \\
Yb & -0.24 & 0.92 & 0.16 & -0.14 & 0.04 & 0.12 \\
Lu & -0.29 & 0.90 & 0.13 & -0.20 & 0.04 & 0.12 \\
Sand & -0.20 & 0.31 & 0.00 & -0.92 & 0.00 & 0.04 \\
Silt & 0.18 & -0.28 & -0.05 & 0.91 & -0.09 & -0.07 \\
Clay & 0.20 & -0.33 & 0.26 & 0.65 & 0.44 & 0.14 \\
\% of variance & 36.8 & 36.8 & 6.7 & 6.7 & 3.9 & 3.0 \\
\% of total variance & 36.8 & 73.6 & 80.3 & 87.1 & 91.0 & 94.0 \\
\hline
\end{tabular}

The third principal component (PC3) accounted for only $6.7 \%$ of the variance and was characterized by a high correlation with $\mathrm{Mo}$, a negative $\mathrm{Na}_{2} \mathrm{O}$ correlation, and relatively high positive correlations with In and W. The fourth principal component (PC4) accounted for $6.7 \%$ of the variance and had a negative sand correlation and positive silt and clay correlations. Although high $\mathrm{Na}_{2} \mathrm{O}$ concentrations $(>0.8 \%)$ were observed in the sediments near the Pahang, Endau, and Kelantan river mouths, the concentrations of $\mathrm{Na}_{2} \mathrm{O}$ were lower $(<0.6 \%)$ than those of $\mathrm{TiO}_{2}$ in sediments to the north (Figure $4 \mathrm{~d}$ ).

The fifth and sixth principal components (PC5 and PC6) accounted for 3.9\% and 3.0\% of the total variance, respectively, and were characterised by high correlations with $\mathrm{CaO}$ and $\mathrm{MnO}$ and a high $\mathrm{Cu}$ correlation, respectively. The surface sediments on the outer Sunda Shelf contained high $\mathrm{CaO}$ concentrations $(>8 \%)$, while those in the coastal area contained low $\mathrm{CaO}$ concentrations $(<4 \%)$, which is indicative of a marine $\mathrm{CaO}$ source (Figure $4 \mathrm{e}$ ). High $\mathrm{Cu}$ concentrations ( $>30 \mathrm{ppm}$ ), which are likely associated with terrestrial human activity, were only observed near the Pahang and Endau river mouths (Figure 4f).

To further determine the common variability of the various proxies to better trace the sediment sources of the coarse-grained components in the study area, a PCA was also carried out on the concentrations of 23 heavy and 8 light minerals in the surface sediment samples. These 31 detrital minerals were grouped into 11 assemblages, which explained $83.8 \%$ of the total variance (Table 3 ).

Table 3. Principal component analysis results for light and heavy minerals in the surface sediment samples from the Sunda Shelf.

\begin{tabular}{|c|c|c|c|c|c|c|c|c|c|c|c|}
\hline Minerals & PC1 & PC2 & PC3 & PC4 & PC5 & PC6 & PC7 & PC8 & PC9 & PC10 & PC11 \\
\hline hornblende & 0.04 & 0.01 & 0.60 & 0.13 & 0.22 & 0.15 & 0.05 & 0.16 & 0.00 & 0.53 & 0.24 \\
\hline tremolit & 0.81 & -0.01 & -0.03 & -0.04 & -0.12 & 0.19 & 0.10 & 0.17 & -0.05 & 0.04 & -0.30 \\
\hline epidote & 0.51 & -0.05 & -0.03 & -0.06 & 0.05 & 0.28 & 0.54 & 0.20 & -0.20 & 0.42 & -0.06 \\
\hline biotite & -0.03 & -0.07 & -0.09 & -0.11 & -0.13 & -0.02 & 0.31 & 0.18 & 0.79 & 0.12 & 0.12 \\
\hline muscovite (1) & -0.10 & -0.12 & -0.02 & -0.12 & -0.04 & -0.11 & -0.13 & -0.19 & 0.07 & 0.83 & 0.11 \\
\hline sericite & -0.01 & 0.02 & 0.04 & -0.03 & 0.02 & 0.90 & -0.02 & -0.02 & -0.02 & 0.02 & -0.02 \\
\hline garnet & 0.80 & 0.45 & -0.05 & -0.03 & -0.06 & -0.15 & -0.01 & -0.07 & -0.01 & -0.01 & 0.13 \\
\hline chlorite(1) & -0.07 & -0.12 & -0.07 & -0.11 & -0.13 & 0.00 & -0.01 & -0.07 & -0.20 & -0.12 & -0.57 \\
\hline apatite & 0.94 & 0.03 & 0.01 & 0.06 & -0.03 & -0.03 & 0.09 & 0.02 & 0.03 & 0.05 & -0.07 \\
\hline sphene & 0.82 & -0.01 & -0.01 & 0.03 & 0.02 & -0.09 & -0.05 & -0.07 & -0.06 & -0.16 & 0.28 \\
\hline zircon & 0.06 & 0.89 & -0.11 & -0.10 & -0.04 & -0.05 & 0.01 & 0.00 & -0.18 & -0.05 & 0.17 \\
\hline augite & 0.43 & -0.20 & -0.17 & 0.16 & -0.07 & -0.02 & 0.21 & -0.30 & -0.35 & -0.11 & 0.43 \\
\hline hypersthene & 0.40 & 0.18 & -0.01 & 0.02 & 0.21 & -0.14 & 0.81 & -0.07 & 0.02 & -0.08 & -0.09 \\
\hline siderite & 0.09 & -0.08 & -0.07 & 0.87 & -0.11 & -0.07 & -0.19 & 0.09 & -0.02 & -0.08 & 0.00 \\
\hline ilmenite & 0.12 & 0.92 & -0.12 & -0.12 & 0.00 & -0.14 & 0.11 & -0.03 & -0.11 & -0.02 & 0.00 \\
\hline magnetite & 0.17 & 0.21 & -0.13 & -0.01 & 0.43 & -0.17 & 0.22 & -0.12 & -0.08 & -0.12 & -0.62 \\
\hline limmonite & -0.27 & -0.48 & -0.29 & -0.60 & -0.10 & 0.04 & -0.28 & -0.12 & -0.19 & -0.21 & -0.05 \\
\hline hematite & -0.04 & 0.00 & 0.92 & -0.04 & -0.05 & 0.07 & 0.11 & -0.13 & -0.05 & 0.09 & -0.03 \\
\hline leucoxene & -0.10 & 0.02 & -0.09 & -0.10 & 0.89 & -0.13 & 0.14 & 0.14 & -0.09 & 0.01 & 0.05 \\
\hline pyrite & -0.05 & -0.03 & 0.95 & 0.02 & -0.07 & -0.06 & 0.07 & -0.06 & -0.07 & -0.12 & 0.06 \\
\hline rhodochrosite & -0.10 & -0.09 & -0.06 & 0.14 & 0.09 & -0.11 & -0.09 & 0.82 & 0.01 & -0.04 & 0.08 \\
\hline olivine & -0.06 & 0.50 & 0.01 & 0.09 & 0.34 & -0.11 & -0.13 & -0.30 & 0.09 & -0.10 & -0.26 \\
\hline
\end{tabular}


Table 3. Cont.

\begin{tabular}{|c|c|c|c|c|c|c|c|c|c|c|c|}
\hline Minerals & PC1 & PC2 & PC3 & PC4 & PC5 & PC6 & PC7 & PC8 & PC9 & PC10 & PC11 \\
\hline detritals & -0.16 & 0.06 & 0.40 & -0.05 & -0.05 & -0.09 & 0.79 & -0.01 & 0.13 & -0.14 & 0.04 \\
\hline quartz & -0.06 & 0.74 & 0.25 & -0.07 & 0.34 & 0.36 & 0.09 & -0.06 & 0.13 & -0.02 & -0.18 \\
\hline plagioclase & -0.08 & 0.18 & 0.04 & -0.07 & 0.85 & 0.29 & -0.06 & -0.10 & -0.09 & 0.04 & 0.00 \\
\hline k-feldspar & -0.14 & -0.12 & -0.22 & 0.74 & -0.14 & 0.05 & 0.13 & -0.16 & -0.25 & -0.07 & 0.17 \\
\hline muscovite(2) & -0.08 & -0.12 & -0.08 & -0.04 & -0.09 & 0.33 & -0.17 & -0.18 & 0.78 & -0.06 & 0.14 \\
\hline weathered mica & -0.05 & -0.07 & -0.04 & -0.12 & 0.06 & 0.81 & -0.13 & -0.11 & 0.40 & -0.10 & 0.12 \\
\hline glauconite & 0.48 & 0.07 & -0.19 & 0.01 & -0.22 & -0.03 & 0.20 & 0.65 & 0.02 & -0.22 & 0.04 \\
\hline chlorite(2) & -0.01 & -0.08 & 0.45 & 0.74 & 0.07 & -0.15 & -0.01 & 0.27 & -0.02 & -0.02 & 0.05 \\
\hline bioclast & -0.19 & -0.63 & -0.25 & -0.18 & -0.34 & -0.29 & -0.16 & -0.37 & -0.10 & 0.13 & 0.10 \\
\hline$\%$ of variance & 12.8 & 11.4 & 9.3 & 7.9 & 7.5 & 7.1 & 6.9 & 5.9 & 5.9 & 4.6 & 4.6 \\
\hline$\%$ of total variance & 12.8 & 24.2 & 33.5 & 41.4 & 48.9 & 56.0 & 62.9 & 68.8 & 74.7 & 79.3 & 83.8 \\
\hline
\end{tabular}

Note: Chlorite and muscovite with labels (1) and (2) indicate the corresponding heavy and light mineral components, respectively.

PC1 explained $12.8 \%$ of the total variance, with positive correlations with tremolite, epidote, garnet, apatite, and sphene. The high-content regions for most minerals were located offshore. PC2 explained $11.4 \%$ of the total variance and had positive correlations with zircon, ilmenite, olivine, and quartz and a negative correlation with bioclasts. Most of these minerals originate from terrigenous weathering and erosion. The other nine principal components explained less than $10 \%$ of the total variance.

\subsection{Sediment Provenance}

We found that the sediments derived from the Kelantan, Pahang, and Endau rivers were characterised by high percentages of REEs, $\mathrm{Al}_{2} \mathrm{O}_{3}$, and $\mathrm{Na}_{2} \mathrm{O}$. Sediment from the Kelantan River was additionally characterised by high percentages of garnet and glauconite, while sediments from the Pahang and Endau rivers were also characterised by high percentages of quartz, plagioclase, and magnetite. Therefore, the study area can be divided into four potential provenances according to the spatial distributions of the above elements and detrital minerals in the surface sediment samples from the rivers and the neighbouring shelf (Figure 6).

Province I is located in the northwestern part of the study area, where the Kelantan River and the Gulf of Thailand are the dominant sediment sources. In the surface sediment samples from this province, the concentrations of $\mathrm{TiO}_{2}, \mathrm{Na}_{2} \mathrm{O}$, garnet, siderite, and glauconite were higher than those in the other provinces. Clay mineral analyses of the surface sediments further indicate that few materials in the coastal regions of the southwestern Gulf of Thailand originated from the Malay Peninsula [7,15]. Puchala et al. (2011) also concluded that the Kelantan River transports terrestrial materials to this province [23], which was determined using major and trace elemental analyses of surface sediments from the neighbouring western Gulf of Thailand [24].

Province II is located near the Pahang and Endau river mouths, where these two large rivers undoubtedly transport most of the sediments into the province. The percentages of $\mathrm{TiO}_{2}, \mathrm{REEs}, \mathrm{Al}_{2} \mathrm{O}_{3}$, quartz, plagioclase, hypersthene, and magnetite were typically higher in the surface sediment samples from this province than in other provinces. This finding can be explained by the fact that most elements are confined to sediment particles, particularly the clay fraction [25], while quartz and plagioclase are mainly contained in the coarse fraction [26-29].

Province III is located in the northeastern and eastern parts of the study area and is characterised by relatively high hornblende and biotite percentages in the surface sediments. The minerals in these samples were all fine-grained terrigenous minerals; thus, they may have been transported by the Mekong River. The Mekong River is the largest river in Southeast Asia and can re-suspend and transport sediments south-westward during the winter [30]. The other parts of the study area comprise Province IV, wherein the elemental and mineral concentrations of the surface sediments are between the concentrations of the 
other three provinces. Thus, Province IV likely reflects a mixed source, including the Malay Peninsula and the Mekong River.

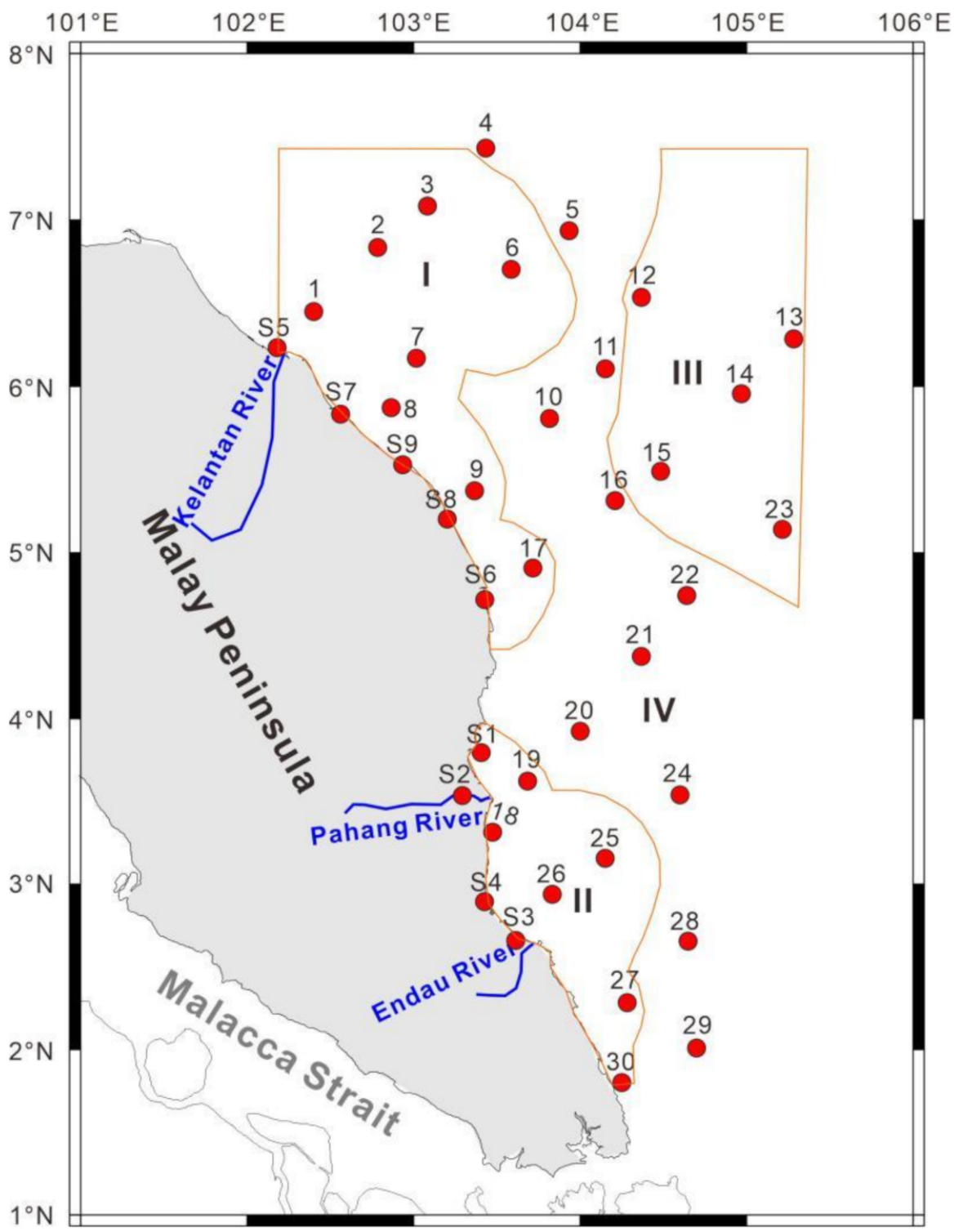

Figure 6. Divisions of the various sediment sources (Provinces I-IV) on the southwestern Sunda Shelf near the Malay Peninsula. Orange lines represent the estimated boundaries of the combined geochemical and mineral provinces in the study area.

\subsection{Sediment Dispersion}

Based on the provenance analyses of the elements and minerals, we can determine the dispersal patterns of terrigenous sediments transported by rivers on the Malay Peninsula, as well as surrounding rivers. Province I is located in the northwestern part of the study area. Due to the fine grain sizes [31], sediments derived from the Kelantan River can be re-suspended and transported south-eastward by winter monsoon winds and deposited in the neighbouring area of the Malay Peninsula [11], while some sediment from the Gulf of Thailand is transported into the northwestern part of the study area [7].

Province II is located offshore of the Pahang and Endau rivers. Sediments from the Pahang and Endau rivers are mostly deposited at the river mouths and in the adjacent shore areas, owing to the coarser grain sizes of the river sediments [31]. A strong coastal current driven by the northeast monsoon is considered to be the main current system in this region, 
which could transport sediment from the Pahang and Endau rivers to offshore areas. The Pahang River, as the largest river on the Malay Peninsula, transports 20.4 Mt of terrigenous materials into the southern SCS annually [24]. Under the effects of coastal currents and waves, the sediment is sorted and coarse sediments are deposited in the estuaries, while the fine-grained fraction can be transported a long distance southward [11,32].

Province III is located in the northeastern and eastern parts of the study area, with finer grain sizes than in the other provinces. The Mekong River is the largest river in Southeast Asia and deposits a huge amount of sediment near its mouth annually [30], making it the most important sediment source for the SCS [24]. A previous study determined that there was no significant export of fine-grained Mekong River-derived sediment into the deep region of the SCS [33] and that $25 \%$ of the sediment from the Mekong River accumulated on the shelf around the Camau Peninsula. During the winter, the southwestward coastal current could cause re-suspension and south-westward transport of these Mekong River sediments [30]. With stronger northeast monsoon currents, suspended fine-grained sediment from the Mekong River may be transported to the southwest for long distances to reach the northeastern part of the study area [11]. Province IV is located in the central part of the study area and probably reflects a mixed source from the Malay Peninsula and the Mekong River under the influence of the northeastern monsoon.

Similar to the East China Sea Shelf, they both include a large river and mountainous small rivers in the surrounding mainland. Although the Yangtz River supplies huge amount of sediment to the East China Sea Shelf, the mountainous small rivers in southeast China and Taiwan are also nonnegligible potential provenances [34,35], and sometimes they can provide disproportionate amounts of sediment during typhoons or extreme events. Therefore, our study about sediment distribution and dispersion in the Western Sunda Shelf is helpful for us to understand the role of mountainous rivers in global shelf sediments source and sink.

\section{Conclusions}

Multiple proxies, i.e., grain size, elemental geochemistry, and detrital minerals, were analysed in the surface sediments to investigate sediment sources and transport in the WSSMP. In the study area, surface sediments were generally poorly sorted and transportable. A PCA of the geochemical elements obtained seven major assemblages that accounted for $94.0 \%$ of the total variance, which indicates similar origins for the sediments, as well as the controlling effect of grain size. The light and heavy minerals in the surface sediment samples were analysed to improve sediment provenance identification in the WSSMP. The study area can be divided into four sediment provinces based on their elemental and mineral distributions. Province I is located in the northwestern part of the study area, where the Kelantan River and the Gulf of Thailand are the dominant sediment sources. Province II is located offshore of the Pahang and Endau rivers, where the two large rivers are the sources of most of the sediments in this region. Coastal currents, driven by the northeastern monsoon, are transporting sediment from the Pahang and Endau rivers to the river mouths and offshore areas. Province III is located in the northeastern and eastern parts of the study area, where sediments contain relatively high percentages of hornblende and biotite. The Mekong River is the major source of sediment to this region, owing to re-suspension and south-westward transport under the effects of the northeastern monsoon. The rest of the study area comprises Province IV, where the mineral concentrations in the surface sediments are generally between those of the other three provinces, suggesting a mixed source.

Author Contributions: Conceptualization, Y.L. and C.L.; methodology, C.L.; software, C.L.; validation, Y.L. and C.L.; formal analysis, Y.L.; investigation, R.B.O. and N.N.F.; resources, C.L.; data curation, C.L. and H.Z.; writing-original draft preparation, C.L. and Y.L.; writing-review and editing, Y.L., C.L. and X.S.; visualization, Y.L.; supervision, X.S.; project administration, Y.L.; funding acquisition, Y.L. All authors have read and agreed to the published version of the manuscript. 
Funding: This work was jointly supported by the NSFC-Shandong Joint Fund for Marine Science Research Centers (U1606401) and the National Programme on Global Change and Air-Sea Interaction (GASI-01-02-01-04).

Institutional Review Board Statement: Not applicable.

Informed Consent Statement: Not applicable.

Data Availability Statement: The data used to support the findings of this study are available from the corresponding author upon request.

Acknowledgments: We are thankful to the National University of Malaysia for providing surface sediment samples from the Sunda Shelf.

Conflicts of Interest: The authors declare no conflict of interest.

\section{References}

1. Steinke, S.; Kienast, M.; Hanebuth, T. On the significance of sea-level variations and shelf paleo-morphology in governing sedimentation in the southern South China Sea during the last deglaciation. Mar. Geol. 2003, 201, 179-206. [CrossRef]

2. Milliman, J.D.; Fornworth, K.M. River Discharge to the Coastal Ocean: A Global Synthesis; Cambridge University Press: Cambridge, UK, 2011.

3. Hanebuth, T.J.; Voris, H.; Yokoyama, Y.; Saito, Y.; Okuno, J. Formation and fate of sedimentary depocentres on Southeast Asia's Sunda Shelf over the past sea-level cycle and biogeographic implications. Earth-Sci. Rev. 2011, 104, 92-110. [CrossRef]

4. Huang, J.; Jiang, F.; Wan, S.; Zhang, J.; Li, A.; Li, T. Terrigenous supplies variability over the past 22,000yr in the southern South China Sea slope: Relation to sea level and monsoon rainfall changes. J. Asian Earth Sci. 2016, 117, 317-327. [CrossRef]

5. Tahir, N.M.; Pang, S.Y.; Simoneit, B.R.T. Distribution and sources of lipid compound series in sediment cores of the southern South China Sea. Environ. Sci. Pollut. Res. 2015, 22, 7557-7568. [CrossRef] [PubMed]

6. Setiawan, R.Y.; Mohtadi, M.; Southon, J.; Groeneveld, J.; Steinke, S.; Hebbeln, D. The consequences of opening the Sunda Strait on the hydrography of the eastern tropical Indian Ocean. Paleoceanography 2015, 30, 1358-1372. [CrossRef]

7. Shi, X.; Liu, S.; Fang, X.; Qiao, S.; Khokiattiwong, S.; Kornkanitnan, N. Distribution of clay minerals in surface sediments of the western Gulf of Thailand: Sources and transport patterns. J. Asian Earth Sci. 2015, 105, 390-398. [CrossRef]

8. Liu, S.; Shi, X.; Yang, G.; Khokiattiwong, S.; Kornkanitnan, N. Distribution of major and trace elements in surface sediments of the western Gulf of Thailand: Implications to modern sedimentation. Cont. Shelf Res. 2016, 117, 81-91. [CrossRef]

9. Khadijeh, R.E.S.; Elias, S.B.; Wood, A.K.; Reza, A.M. Rare earth elements distribution in marine sediments of Malaysia coasts. J. Rare Earths 2009, 27, 1066-1071. [CrossRef]

10. Adiana, G.; Shazili, N.A.M.; Marinah, M.A.; Bidai, J. Effects of northeast monsoon on trace metal distribution in the South China Sea off Peninsular Malaysia. Environ. Monit. Assess. 2013, 186, 421-431. [CrossRef]

11. Wu, K.; Liu, S.; Shi, X.; Lou, Z.; Kandasamy, S.; Wu, B.; Wang, K.; Cao, P.; Zhang, H.; Mohamed, C.A.R. Distribution of rare earth elements in surface sediments of the western Sunda Shelf: Constraints from sedimentology and mineralogy. Cont. Shelf Res. 2020, 206, 104198. [CrossRef]

12. Hutchison, C.S. Dating Tectonism in the Indosinian-Thai-Malayan Orogen by Thermoluminescence. GSA Bull. 1968, 79, 375. [CrossRef]

13. Sultan, K.; Shazili, N.A. Distribution and geochemical baselines of major, minor and trace elements in tropical topsoils of the Terengganu River basin, Malaysia. J. Geochem. Explor. 2009, 103, 57-68. [CrossRef]

14. Commission for the Geological Map of the World. Geological World Atlas; Scale 1:10,000,000; UNESCO Press: Paris, France, 1977.

15. Wang, H.; Liu, Z.; Sathiamurthy, E.; Colin, C.; Li, J.; Zhao, Y. Chemical weathering in Malay Peninsula and North Borneo: Clay mineralogy and element geochemistry of river surface sediments. Sci. China Earth Sci. 2011, 54, 272-282. [CrossRef]

16. Liu, Z.; Wang, H.; Hantoro, W.S.; Sathiamurthy, E.; Colin, C.; Zhao, Y.; Li, J. Climatic and tectonic controls on chemical weathering in tropical Southeast Asia (Malay Peninsula, Borneo, and Sumatra). Chem. Geol. 2012, 291, 1-12. [CrossRef]

17. Tangang, F.; Xia, C.; Qiao, F.; Juneng, L.; Shan, F. Seasonal circulations in the Malay Peninsula Eastern continental shelf from a wave-tide-circulation coupled model. Ocean Dyn. 2011, 61, 1317-1328. [CrossRef]

18. McManus, J. Grain size determination and interpretation. In Techniques in Sedimentology; Tucker, M., Ed.; Blackwell: Oxford, UK, 1988; pp. 63-85.

19. Folk, R.L.; Andrews, P.B.; Lewis, D.W. Detrital sedimentary rock classification and nomenclature for use in New Zealand. N. Z. J. Geol. Geophys. 1970, 13, 937-968. [CrossRef]

20. Liu, Z.S.; Zhao, H.T.; Fan, S.Q.; Chen, S.Q. Geology of the South China Sea; China Science Press: Beijing, China, $2020 ;$ pp. $204-232$.

21. Liu, J.; Chen, Z.; Chen, M.; Yan, W.; Xiang, R.; Tang, X. Magnetic susceptibility variations and provenance of surface sediments in the South China Sea. Sediment. Geol. 2010, 230, 77-85. [CrossRef]

22. Charriau, A.; Lesven, L.; Gao, Y.; Leermakers, M.; Baeyens, W.; Ouddane, B.; Billon, G. Trace metal behaviour in riverine sediments: Role of organic matter and sulfides. Appl. Geochem. 2011, 26, 80-90. [CrossRef] 
23. Puchała, R.J.; Porebski, S.J.; Śliwiński, W.R.; August, C.J. Pleistocene to Holocene transition in the central basin of the Gulf of Thailand, based on geoacoustic survey and radiocarbon ages. Mar. Geol. 2011, 288, 103-111. [CrossRef]

24. Liu, Z.; Zhao, Y.; Colin, C.; Stattegger, K.; Wiesner, M.G.; Huh, C.-A.; Zhang, Y.; Li, X.; Sompongchaiyakul, P.; You, C.-F.; et al. Source-to-sink transport processes of fluvial sediments in the South China Sea. Earth-Sci. Rev. 2016, 153, 238-273. [CrossRef]

25. Zhao, Y.Y.; Yan, M.C. Geochemistry of Sediments in Chinese Shallow Seas; Science Press: Beijing, China, 1994.

26. McManus, D.A. Modern Versus Relict Sediment on the Continental Shelf. GSA Bull. 1975, 86, 1154-1160. [CrossRef]

27. Shi-Guo, W.; Wong, H.K.; You-Lang, L.; Zhi-Rong, L. Distribution and origin of sediments on the northern Sunda Shelf, South China Sea. Chin. J. Oceanol. Limnol. 1999, 17, 28-40. [CrossRef]

28. Steinke, S.; Hanebuth, T.J.; Vogt, C.; Stattegger, K. Sea level induced variations in clay mineral composition in the southwestern South China Sea over the past 17,000 yr. Mar. Geol. 2008, 250, 199-210. [CrossRef]

29. Zhao, Y.; Liu, Z.; Colin, C.; Xie, X.; Wu, Q. Turbidite deposition in the southern South China Sea during the last glacial: Evidence from grain-size and major elements records. Chin. Sci. Bull. 2011, 56, 3558-3565. [CrossRef]

30. Xue, Z.; He, R.; Liu, P.; Warner, J.C. Modeling transport and deposition of the Mekong River sediment. Cont. Shelf Res. 2012, 37, 66-78. [CrossRef]

31. Wu, K.; Liu, S.; Kandasamy, S.; Jin, A.; Lou, Z.; Li, J.; Wu, B.; Wang, X.; Mohamed, C.A.; Shi, X. Grain-size effect on rare earth elements in Pahang River and Kelantan River, Peninsular Malaysia: Implications for sediment provenance in the southern South China Sea. Cont. Shelf Res. 2019, 189, 103977. [CrossRef]

32. Mallinson, D.J.; Culver, S.J.; Corbett, D.R.; Parham, P.R.; Shazili, N.A.M.; Yaacob, R. Holocene coastal response to monsoons and relative sea-level changes in northeast peninsular Malaysia. J. Asian Earth Sci. 2014, 91, 194-205. [CrossRef]

33. Szczuciński, W.; Jagodziński, R.; Hanebuth, T.J.; Stattegger, K.; Wetzel, A.; Mitrega, M.; Unverricht, D.; Van Phach, P. Modern sedimentation and sediment dispersal pattern on the continental shelf off the Mekong River delta, South China Sea. Glob. Planet. Chang. 2013, 110, 195-213. [CrossRef]

34. Xu, K.; Milliman, J.D.; Li, A.; Liu, P.; Kao, S.-J.; Wan, S. Yangtze- and Taiwan-derived sediments on the inner shelf of East China Sea. Cont. Shelf Res. 2009, 29, 2240-2256. [CrossRef]

35. Jian, X.; Yang, S.; Hong, D.; Liang, H.; Zhang, S.; Fu, H.; Zhang, W. Seasonal geochemical heterogeneity of sediments from a subtropical mountainous river in SE China. Mar. Geol. 2020, 422, 106120. [CrossRef] 